\title{
Anti-inflammatory activity of the topical formulation of Drymoglossum piloselloides (L) Presl. extract on mice
}

\section{Uji aktivitas anti-inflamasi sediaan topikal ekstrak daun paku sisik naga (Drymoglossum piloselloides (L) Presl.) pada mencit}

\author{
Putu Era Sandhi Kusuma Yuda ${ }^{1 *}$, Ni Putu Dewanty Suwirtawati ${ }^{1}$, Ni Luh Kade Arman Anita \\ Dewi $^{1}$
}

${ }^{1}$ Department of Natural Medicine, Faculty of Pharmacy, Universitas Mahasaraswati Denpasar

*Corresponding author: erasandhi@unmas.ac.id

\begin{abstract}
Background: Chronic inflammation of the joints that occur in the condition of gout or osteoarthritis and rheumatoid arthritis often causes repeated inflammation which requires patients to take a long-term pain medication, leading to serious side effects. Alternative treatment especially from herbal ingredients in a topical form is needed.

Objective: This study aims to evaluate the anti-inflammatory activity of the leaves extract of Drymoglossum piloselloides (L) Presl. in mice to prove their potential as an anti-inflammatory agent.

Methods: Mice were divided into four groups ( $n=7)$, namely positive control (sodium diclofenac emulgel), negative control (placebo), P1 (emulgel extract 2.5\%), and P2 (emulgel extract 5\%). The anti-inflammatory activity test was carried out on mice with carrageenan-induced paw edema by measuring the relative changes in the volume of inflammation at 0 and 3 hours after treatment. Data were analyzed using the Kruskal-Wallis and Mann-Whitney tests with a confidence level of $95 \%$.

Results: The emulgel contained flavonoids, triterpenoids, steroids, tannins, and quinones. The antiinflammatory test showed a significant inhibition of inflammation $(\mathrm{p}<0.05)$ at concentrations of $2.5 \%$ and $5 \%$. This anti-inflammatory activity could be influenced by the phytochemical compounds contained in the emulgel.

Conclusion: Drymoglossum piloselloides (L) Presl. emulgel at concentrations of $2.5 \%$ and $5 \%$ had an antiinflammatory activity on mice with carrageenan-induced paw edema.

Keywords: inflammation, Drymoglossum piloselloides (L) Presl., emulgel

\section{Intisari}

Latar belakang: Peradangan kronis pada persendian dapat terjadi pada kondisi gout ataupun osteoartritis dan rheumatoid arthritis (RA) sering kali menimbulkan inflamasi berulang yang mengharuskan pasien mengkonsumsi obat nyeri atau anti-inflamasi nonsteroid dan kortikosteroid dalam waktu lama sehingga dapat menimbulkan efek samping yang serius, sehingga diperlukan alternatif pengobatan yang relatif lebih aman terutama dari bahan herbal dalam bentuk topikal.

Tujuan: Penelitian ini bertujuan untuk menguji aktivitas antiinflamasi emulgel ekstrak daun paku sisik naga (Drymoglossum piloselloides (L) Presl.) pada mencit untuk membuktikan potensinya sebagai anti-inflamasi.

Metode: Mencit dibagi empat kelompok ( $n=7)$ yaitu kontrol positif (emulgel natrium diklofenak), kontrol negatif (placebo), P1 (emulgel ekstrak konsentrasi 2,5\%) dan P2 (emulgel ekstrak konsentrasi 5\%). Selanjutnya dilakukan pengujian anti-inflamasi pada mencit paw edema yang diinduksi karagenan dengan mengukur perubahan volume peradangan kaki mencit pada jam ke-0 dan jam ke-3 setelah perlakuan. Data selanjutnya dianalisis menggunakan uji Kruskal-Wallis dan Mann-Whitney dengan taraf kepercayaan 95\%.

Hasil: Hasil uji aktivitas anti-inflamasi menunjukan adanya penghambatan peradangan yang signifikan $(\mathrm{p}<0,05)$ baik pada konsentrasi 2,5\% maupun maupun 5\% pada jam ke-3.

Kesimpulan: Emulgel ekstrak daun paku sisik naga konsentrasi 2,5\% dan 5\% memiliki aktivitas antiinflamasi pada paw edema mencit yang diinduksi karagenan.

Kata kunci : inflamasi, Drymoglossum piloselloides (L) Presl., emulgel
\end{abstract}


138 | Yuda, dkk /Jurnal Ilmiah Farmasi (Scientific Journal of Pharmacy) 17(2) Agustus-Desember 2021, 137144

\section{Pendahuluan}

Gout ditandai dengan peradangan sendi yang menyakitkan dan paling sering terjadi pada sendi metatarsophalangeal akibat pengendapan kristal monosodium urat pada ruang sendi. Diagnosis dapat dipastikan dengan melakukan identifikasi kristal monosodium urat dalam cairan sinovial sendi yang terkena. Gout akut dapat diobati dengan obat antiinflamasi nonsteroid, kortikosteroid, atau kolkisin. Untuk mengurangi kemungkinan kekambuhan berulang, pasien harus membatasi konsumsi makanan kaya purin tertentu (jeroan, kerang) dan menghindari minuman beralkohol dan minuman yang dimaniskan dengan sirup jagung fruktosa tinggi (Hainer et al., 2014). Selain itu, gangguan peradangan sendi kronis seperti osteoartritis dan rheumatoid arthritis memiliki kesamaan dalam hal peningkatan gejala peradangan dan stres oksidatif yang mengakibatkan perubahan histologis yang progresif serta gejala yang mengganggu pergerakan. Pengobatan konvensional yang saat ini digunakan (mulai dari penghilang rasa sakit hingga agen biologis) cukup memuaskan, tetapi sering kali dikaitkan dengan efek samping yang serius, bahkan dapat mengancam jiwa (Dragos et al., 2017).

Karena kemanjurannya dalam mengurangi rasa sakit dan peradangan, obat antiinflamasi nonsteroid (NSAID) adalah obat yang paling populer digunakan dan ditempatkan dalam Daftar Obat Esensial oleh WHO. Namun, terlepas dari khasiat analgesik, anti-inflamasi dan antipiretik, data dari beberapa uji coba terkontrol plasebo dan studi meta-analisis secara mengkhawatirkan menunjukkan efek samping NSAID pada komplikasi gastrointestinal, kardiovaskular, hati, ginjal, serebral, dan paru-paru (Bindu et al., 2020).

Pasien gout maupun osteoartritis biasanya menggunakan obat-obat NSAID dalam jangka waktu lama. Melihat adanya efek samping pemakaian NSAID dalam pemakaian jangka panjang, maka diperlukan sebuah pengobatan alternatif ataupun komplementer dengan efek samping yang relatif lebih rendah terutama dari bahan herbal. Tanaman obat telah digunakan selama ribuan tahun dalam jamu tradisional, dan merupakan alternatif yang menjanjikan, dengan tingkat efek samping yang lebih rendah dan efisiensi yang sering kali sebanding dengan obat konvensional walupun mekanisme kerjanya belum diketahui secara pasti.

Salah satu jenis tumbuhan yang telah dimanfaatkan sebagai obat tradisional di Indonesia adalah tanaman paku sisik naga (Drymoglossum piloselloides) dari suku Polypodiaceae. Masyarakat secara tradisional memanfaatkan paku sisik naga untuk mengobati peradangan, sariawan, pendarahan dan sakit gigi. Penelitian menunjukkan bahwa tanaman ini memiliki aktivitas sebagai antibakteri (Heriyati et al., 2016). Namun, aktivitas antiinflamasi dari tanaman ini masih sangat jarang diteliti. Untuk melihat adanya potensi dari tanaman ini sebagai agen antiperadangan 
139 | Yuda, dkk /Jurnal Ilmiah Farmasi (Scientific Journal of Pharmacy) 17(2) Agustus-Desember 2021, 137144

khususnya pada kasus radang persendian, maka pada penelitian ini dilakukan pengujian aktivitas antiinflamasi dari esktrak tanaman paku sisik naga yang dibuat dalam bentuk sediaan topikal. Penggunaan sediaan topikal pada kasus peradangan sendi diharapkan dapat meminimalkan efek samping secara sistemik.

\section{Metode}

\subsection{Alat dan bahan}

Alat-alat yang digunakan pada penelitian ini yaitu alat-alat gelas (Erlenmeyer, beaker glass, tabung reaksi), cawan porselain, drying oven (Memmert, Jerman), rotary evaporator (Buchi, Swiss), dan pletismometer (Orchid, India). Bahan-bahan yang digunakan dalam penelitian ini yaitu tanaman paku sisik naga yang diperoleh dari daerah Badung, Bali. Bagian tanaman yang digunakan adalah bagian daunnya yang berbentuk pipih oval, dengan warna daun yang masih hijau. Bahan lain yang digunakan yaitu tween 80 (Saba Kimia, Indonesia), karbopol (Saba Kimia, Indonesia), trietanolamin (Saba Kimia, Indonesia), akuades, etanol 96\% (Brataco Chemical, Indonesia), kloroform (Merck, Jerman), amonia (Merck, Jerman), asam sulfat (Merck, Jerman), pereaksi Dragendorff, pereaksi Mayer, asam klorida pekat, natrium hidroksida 25\%, asam asetat anhidrat, besi III klorida, karagenan (Sigma, USA), emulgel Voltaren ${ }^{\circledR}$ (Novartis, Indonesia). Hewan percobaan yang digunakan dalam penelitian ini adalah mencit jantan putih galur Balb/C berumur dua bulan dengan berat 20 -30 gram $(21,5 \pm 1,87 \mathrm{~g})$.

\subsection{Pembuatan ekstrak etanol daun paku sisik naga}

Sebanyak 330 g serbuk simplisia kering tanaman paku sisik naga dimaserasi dengan $500 \mathrm{ml}$ etanol 96\% selama lima hari. Filtrat disaring lalu diuapkan dengan menggunakan rotary evaporator hingga diperoleh ekstrak kental.

\subsection{Pembuatan emulgel ekstrak daun paku sisik naga}

Karbopol direndam dengan air panas kemudian dihomogenkan hingga mengembang dan ditambahkan trietanolamin sampai terbentuk massa gel yang jernih. Fase minyak yang terdiri dari campuran span 20, parafin cair, dan metil paraben dipanaskan pada suhu $70^{\circ} \mathrm{C}$ hingga homogen. Fase air terdiri dari campuran tween 80, propilen glikol, propil paraben, dan akuades dipanaskan pada suhu $70^{\circ} \mathrm{C}$ hingga homogen. Semua bahan dicampur dan dihomogenisasi sampai terbentuk emulgel yang stabil. 
140 | Yuda, dkk /Jurnal Ilmiah Farmasi (Scientific Journal of Pharmacy) 17(2) Agustus-Desember 2021, 137144

Tabel 1. Formula emulgel ekstrak paku sisik naga

\begin{tabular}{cllcc}
\hline \multirow{2}{*}{ Komponen } & \multicolumn{2}{c}{ Bahan } & \multicolumn{2}{c}{ Formula (\%) } \\
\cline { 2 - 4 } & & P1 & P2 \\
\hline \multirow{5}{*}{ Fase air } & Ekstrak Paku Sisik Naga & 2,5 & 5 \\
& Carbopol & 8,5 & 8,5 \\
\cline { 2 - 4 } & TEA & qs & qs \\
\cline { 2 - 4 } & Tween 80 & 17,5 & 17,5 \\
\cline { 2 - 4 } & Propilene glycol & 2,5 & 2,5 \\
\cline { 2 - 4 } & Propil paraben & 0,015 & 0,015 \\
\cline { 2 - 4 } & Aquadest & $\mathrm{Ad} \mathrm{100}$ & $\mathrm{Ad} 100$ \\
\cline { 2 - 4 } Fase minyak & Etanol 96\% & 5 & 5 \\
& Metil paraben & 0,1 & 0,1 \\
\cline { 2 - 4 } & Paraffin cair & 2,5 & 2,5 \\
\cline { 2 - 4 } & Span 20 & 12,5 & 12,5 \\
\hline
\end{tabular}

\subsection{Skrining fitokimia emulgel}

Skrining fitokimia dilakukan dengan metode yang digunakan oleh Kumar et al. (2013) menggunakan sampel dalam bentuk larutan uji kemudian direaksikan dengan pereaksi fitokimia. Untuk uji flavonoid digunakan pereaksi ammonia dan asam sulfat pekat dan natrium hidroksida. Hasil positif flavonoid ditunjukan dengan adanya endapan berwarna kuning. Uji tanin menggunakan pereaksi besi (III) klorida 1\% yang mana hasil positifnya ditunjukkan dengan adanya endapan berwarna hitam kehijauan. Uji triterpenoid menggunakan larutan uji kloroform yang ditambahkan asam sulfat pekat. Hasil positif triterpenoid ditunjukkan dengan adanya lapisan cincin berwarna coklat. Uji steroid menggunakan larutan uji kloroform dan ditambahkan pereaksi Lieberman Burchard. Hasil positif steroid menunjukan adanya perubahan warna biru atau hijau. Uji alkaloid menggunakan pereaksi Dragendorff yang hasil positifnya ditunjukkan dengan adanya endapan coklat. Selain itu, uji alkaloid juga menggunakan pereaksi Mayer yang menunjukkan endapan putih untuk hasil positif. Uji kuinon menggunakan pereaksi natrium hidroksida $1 \mathrm{~N}$ dan hasil positif ditunjukkan dengan munculnya endapan berwarna merah.

\subsection{Pengujian aktivitas anti-inflamasi}

Penelitian ini menggunakan metode eksperimental laboratorium dengan desain penelitian yang Randomized Pre-Test and Post Test with Control Group Design dengan menggunakan 28 ekor mencit jantan berwarna putih dengan berat mencit 20-30 gram yang dibagi menjadi 4 kelompok uji. Prosedur pengujian aktivitas antiinflamasi pada mencit sudah disetujui oleh Komisi Etik Penelitian FK UNUD dengan nomor 1538/UN14.2.2. VII. 14/LT/2020. Sebelum diberikan perlakuan, terlebih dahulu telapak kaki mencit diinduksi inflamasi dengan karagenan 0,5\%. Pada masing-masing kelompok diberikan perlakuan pada kaki mencit yang mengalami edema yaitu sebagai berikut: kelompok 1 (kelompok kontrol positif) dioleskan emulgel natrium diklofenak pada 
141 | Yuda, dkk /Jurnal Ilmiah Farmasi (Scientific Journal of Pharmacy) 17(2) Agustus-Desember 2021, 137144

udem kaki mencit, kelompok 2 (kelompok kontrol negatif) dioleskan plasebo (emulgel tanpa ekstrak), kelompok 3 dioleskan emulgel ekstrak paku sisik naga 2,5\% (P1) dan kelompok 4 dioleskan emulgel paku sisik naga 5\% (P2), masing-masing dengan jumlah yang sama dan diberikan setiap jam sampai 3 jam setelah induksi. Volume udem mencit diukur pada jam ke-0 dan jam ke-3 setelah perlakuan, dengan menggunakan alat pletismometer.

\subsection{Analisis data}

Data volume peradangan ditampilkan dalam nilai persentase peradangan relatif terhadap volume udema sebelum perlakuan (V3/V0 x 100\%). Data tersebut diuji secara statistik dengan program SPSS ${ }^{\circledR} 20$ for Windows menggunakan uji Kruskal-Wallis dengan taraf kepercayaan 95\% untuk melihat adanya perbedaan yang bermakna pada kelompok uji dilanjutkan dengan uji MannWhitney untuk melihat perbedaan yang signifikan antar kelompok.

\section{Hasil dan pembahasan}

Dari proses ekstraksi didapatkan ekstrak kental sebanyak 13,3 gram dengan rendemen ekstrak 9,92\%. Setelah diformulasikan menjadi emulgel, dihasilkan sediaan emulgel berbentuk semi padat dengan warna hijau kekuningan. Berdasarkan uji skrining fitokimia, diperoleh hasil bahwa emulgel tersebut mengandung beberapa golongan senyawa metabolit sekunder yaitu flavonoid, tannin, kuinon, steroid dan triterpenoid (Tabel 2). Hasil penelitian Sagita et al. (2017) menunjukkan bahwa tanaman paku sisik naga mengandung senyawa flavonoid dan tanin, namun tidak ditemukan adanya kandungan alkaloid dan steroid. Perbedaan tersebut dapat dipengaruhi oleh adanya faktor lingkungan atau habitat tanaman yang mengakibatkan adanya perbedaan biosentesis metabolit sekunder pada tanaman tersebut.

Tabel 2. Hasil skrining fitokimia ekstrak paku sisik naga

\begin{tabular}{cc}
\hline Golongan Metabolit Sekunder & Hasil \\
\hline Flavonoid & + \\
Tanin & + \\
Steroid & + \\
Alkaloid & - \\
Kuinon & + \\
Triterpenoid & + \\
\hline
\end{tabular}

Dari gambar 2 terlihat bahwa inflamasi pada kelompok kontrol negatif masih terjadi selama tiga jam setelah induksi dengan karagenan. Di sisi lain, pemberian emulgel natrium diklofenak (kontrol positif) mampu menekan volume peradangan hingga 21\%, emulgel ekstrak paku sisik naga 
142 | Yuda, dkk /Jurnal Ilmiah Farmasi (Scientific Journal of Pharmacy) 17(2) Agustus-Desember 2021, 137144

2,5\% mampu menekan peradangan sebanyak 31\% dan emulgel dengan konsentrasi ekstrak 5\% mampu menekan peradangan sebanyak 21\%, hampir sebanding dengan kontrol positif. Uji KruskalWallis menunjukkan bahwa terdapat kelompok yang memiliki perbedaan volume peradangan relatif yang bermakna $(\mathrm{p}<0,05)$. Dari hasil pengujian Mann-Whitney diketahui bahwa terdapat perbedaan yang bermakna secara statistik pada jam ke-3 antara kelompok kontrol negatif dengan kelompok kontrol positif, kelompok P1, dan kelompok perlakuan P2 $(p<0,05)$. Namun, tidak terdapat perbedaan bermakna secara statistik antara kelompok kontrol positif dengan kelompok P1 dan P2, serta antara kelompok P1 dengan kelompok P2 (p>0,05). Hasil tersebut menunjukkan bahwa emulgel 2,5\% dan emulgel 5\% memiliki efek antiinflamasi yang hampir sama dan kekuatannya sebanding dengan emulgel natrium diklofenak, sehingga dapat disimpulkan bahwa emulgel ekstrak daun paku sisik naga memiliki aktivitas antiinflamasi pada mencit inflamasi yang diinduksi karagenan dengan metode paw edema. Adanya efek antiinflamasi tersebut dapat disebabkan oleh adanya kandungan fitokimia yang terdapat pada ekstrak tersebut, namun untuk mengetahui senyawa yang bertanggungjawab terhadap aktivitas tersebut, perlu dilakukan penelitian lebih lanjut.

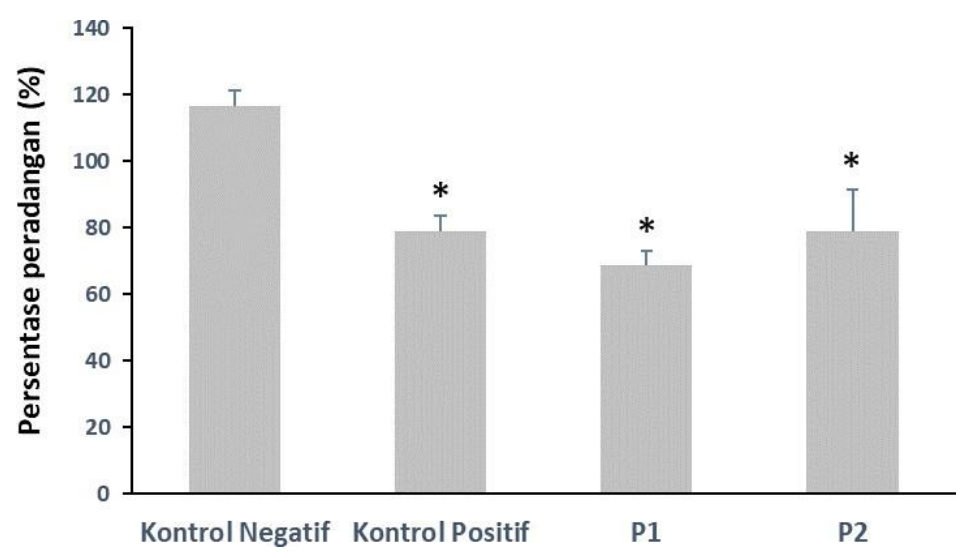

Gambar 2. Hasil pengujian aktivitas antiinflamasi

*: $\mathrm{p}<0,05$ vs kontrol negatif dengan uji Mann-Whitney

Flavonoid diketahui dapat memodulasi ekspresi gen proinflamasi yang mengarah kepada penghambatan respon inflamasi melalui hambatan pada NFKB. Namun demikian, ketersediaan hayati yang rendah dan kemanjuran klinis flavonoid dikaitkan dengan absorbsi yang buruk, metabolisme oleh enzim pemetabolisme di usus dan hati, serta modifikasi struktural oleh bakteri kolon tetap menjadi masalah utama (Choy et al., 2019). Oleh sebab itu, bentuk sediaan topikal dapat 
143 | Yuda, dkk /Jurnal Ilmiah Farmasi (Scientific Journal of Pharmacy) 17(2) Agustus-Desember 2021, 137144

dijadikan sebagai alternatif dalam pemanfaatan flavonoid sebagai antiinflamasi pada kondisi radang persendian. Walaupun secara per oral, ekstrak etanol daun paku sisik naga pada dosis 50, 100, 150, dan $200 \mathrm{mg} / \mathrm{kgBB}$ diketahui tidak menyebabkan efek toksisitas akut secara nyata terhadap nilai darah pada mencit (Yuliastuti \& Efrizal, 2014) dan dari hasil penelitian Malinda (2013) menunjukkan bahwa ekstrak paku sisik naga dapat mencegah proses peroksidasi lipid hati pada dosis efektif $97,02 \mathrm{mg} / \mathrm{KgBB}$.

Hasil penelitian ini juga menunjukkan bahwa ekstrak daun paku sisik naga juga mengandung senyawa tanin. Beberapa penelitian telah menunjukkan bahwa tanin memiliki efek antiinflamasi. Penelitian terbaru menunjukkan bahwa senyawa punicalagin, sebuah senyawa tanin terhidrolisis dari jus buah delima, menunjukkan beberapa efek biologis, termasuk menghambat produksi sitokin proinflamasi di makrofag. Punicalagin memainkan peran penting dalam atenuasi respon inflamasi yang diinduksi LPS di makrofag dan mekanismenya melibatkan downregulation jalur pensinyalan Fox03a/autophagy (Cao et al., 2019). Tanin merupakan golongan senyawa polifenol. Polifenol telah diketahui bermanfaat sebagai terapi adjuvan karena potensi efek antiinflamasinya, terkait dengan aktivitas antioksidan, dan penghambatan enzim yang terlibat dalam produksi eikosanoid. Selain itu tanin juga dapat menghambat stress oksidatif yang menyebabkan terjadinya inflamasi kronis. Stres oksidatif dipandang sebagai ketidakseimbangan antara produksi dan eliminasi spesies oksigen reaktif (ROS) yang dapat menyebabkan peradangan kronis. Stres oksidatif dapat mengaktifkan berbagai faktor transkripsi yang mengarah pada ekspresi diferensial dari beberapa gen yang terlibat dalam jalur inflamasi. Peradangan yang dipicu oleh stres oksidatif adalah penyebab dari berbagai penyakit kronis (Hussain et al., 2016).

Selain flavonoid dan tanin, ekstrak daun paku sisik naga pada penelitian ini juga mengandung steroid dan kuinon. Salah satu subgolongan steroid pada tumbuhan adalah sitosterol. Penelitian menunjukkan bahwa beta-sitosterol memiliki efek antiinflamasi yang signifikan pada berbagai model inflamasi akut pada tikus yang diuji dengan model edema kaki tikus dan radang pleura, uji edema telinga tikus, dan uji aktivitas myeloperoksidase pada tikus (Paniagua-Pérez et al., 2017). Hal tersebut menunjukkan bahwa steroid pada tumbuhan juga memiliki potensi antiinflamasi seperti halnya obat antiinflamasi steroid yang telah banyak digunakan pada pengobatan konvensional. Hal tersebut menjadi salah satu yang menarik untuk diteliti lebih lanjut dalam rangka menemukan kandidat obat baru sebagai agen antiinflamasi.

Dari hasil penelitian ini dapat diketahui bahwa ekstrak daun paku sisik naga dalam bentuk emulgel memiliki aktivitas antiinflamasi. Dengan demikian, sediaan ini berpotensi untuk dikembangkan menjadi alternatif agen antiinflamasi yang dapat digunakan secara topikal. 
144 | Yuda, dkk /Jurnal Ilmiah Farmasi (Scientific Journal of Pharmacy) 17(2) Agustus-Desember 2021, 137144

Penelitian lebih lanjut diperlukan untuk mengetahui mekanisme dari ekstrak tersebut dalam menghambat inflamasi serta senyawa yang bertanggungjawab terhadap aktivitas antiinflamasinya.

\section{Kesimpulan}

Emulgel ekstrak daun paku sisik naga dengan konsentrasi 2,5\% dan 5\% memiliki aktivitas antiinflamasi pada mencit paw edema yang diinduksi karagenan.

\section{Daftar pustaka}

Bindu, S., Mazumder, S., \& Bandyopadhyay, U. (2020). Non-steroidal anti-inflammatory drugs (NSAIDs) and organ damage: A current perspective. Biochem Pharmacol, 180, 114147. doi:10.1016/j.bcp.2020.114147

Cao, Y., Chen, J., Ren, G., Zhang, Y., Tan, X., \& Yang, L. (2019). Punicalagin Prevents Inflammation in LPS-Induced RAW264.7 Macrophages by Inhibiting Fox03a/Autophagy Signaling Pathway. Nutrients, 11(11). doi:10.3390/nu11112794

Choy, K. W., Murugan, D., Leong, X. F., Abas, R., Alias, A., \& Mustafa, M. R. (2019). Flavonoids as Natural Anti-Inflammatory Agents Targeting Nuclear Factor-Kappa B (NFkB) Signaling in Cardiovascular Diseases: A Mini Review. Front Pharmacol, 10, 1295. doi:10.3389/fphar.2019.01295

Dragos, D., Gilca, M., Gaman, L., Vlad, A., Iosif, L., Stoian, I., \& Lupescu, O. (2017). Phytomedicine in Joint Disorders. Nutrients, 9(1). doi:10.3390/nu9010070

Hainer, B. L., Matheson, E., \& Wilkes, R. T. (2014). Diagnosis, Treatment, and Prevention of Gout. American Family Physician, 90(12), 831-836.

Heriyati, H., Khotimah, S., \& Wardoyo, E. R. P. (2016). Aktivitas Antibakteri Fraksi Diklorometan dan N-Heksana Paku Sisik Naga (Drymoglossum piloselloides (L) Presl.) terhadap Bakteri Staphylococcus aureus dan Salmonella typhi. Protobiont, 5 (3), 82-88.

Hussain, T., Tan, B., Yin, Y., Blachier, F., Tossou, M. C., \& Rahu, N. (2016). Oxidative Stress and Inflammation: What Polyphenols Can Do for Us? Oxid Med Cell Longev, 2016, 7432797. doi:10.1155/2016/7432797

Kumar, R. S., Venkateshwar, C., Samuel, G., \& Rao, S. G. (2013). Phytochemical Screening of Some compounds from plant leaf extracts of Holoptelea integrifolia (Planch.) and Celestrus emarginata (Grah.) used by Gondu tribes at Adilabad District, Andhrapradesh, India. International Journal of Engineering Science Invention, 2(8), 65-70.

Malinda, A. F., Fatimawali, F., \& Yudistira, A. (2013). Pengaruh Pemberian Ekstrak Etanol Daun Paku Sisik Naga (Drymoglossum piloselloides l.presl) terhadap Peroksidasi Lipid Hati pada Tikus Jantan Galur Wistar yang Diinduksi CCl4. PHARMACON, 2(2), 72-75.

Paniagua-Pérez, R., Flores-Mondragón, G., Reyes-Legorreta, C., Herrera-López, B., CervantesHernández, I., Madrigal-Santillán, O., Morales-González, J. A., Álvarez-González, I., \& Madrigal-Bujaidar, E. (2017). Evaluation Of The Anti-Inflammatory Capacity Of BetaSitosterol In Rodent Assays. Afr J Tradit Complement Altern Med, 14(1), 123-130.

Sagita, D., Ichwani, M. N., \& Linuria, L. ( 2017). Skrining Aktifitas Antibakteri dari Ekstrak Sisik Naga (Pyyrosia piloselloides (L) M.G.Price). Riset Informasi Kesehatan, 6(2), 115-119.

Yuliastuti, R. R., \& Efrizal, E. (2014). Efek Toksisitas Akut Ekstrak Daun Paku Sisik Naga (Drymoglossum piloselloides (L.) Presl) terhadap Nilai Darah Mencit Putih (Mus musculus L.). J. Bio. UA, 3(4), 332-336. 